\title{
Removal of Cu (II) from Industrial Wastewater Using Mechanically Activated Serpentinite
}

\author{
Petros Petrounias ${ }^{1, *(\mathbb{D}}$, Aikaterini Rogkala ${ }^{1} \mathbb{C}$, Panagiota P. Giannakopoulou ${ }^{1}(\mathbb{D}$, \\ Paraskevi Lampropoulou ${ }^{1}$, Petros Koutsovitis ${ }^{1}{ }^{\circledR}$, Nikolaos Koukouzas ${ }^{2}$, Nikolaos Laskaris ${ }^{3}$, \\ Panagiotis Pomonis ${ }^{4}$ and Konstantin Hatzipanagiotou ${ }^{1}$ \\ 1 Section of Earth Materials, Department of Geology, University of Patras, 26504 Patras, Greece; \\ krogkala@upatras.gr (A.R.); peny_giannakopoulou@windowslive.com (P.P.G.); \\ p.lampropoulou@upatras.gr (P.L.); pkoutsovitis@upatras.gr (P.K.); k.hatzipanagiotou@upatras.gr (K.H.) \\ 2 Chemical Process \& Energy Resources Institute, Centre for Research \& Technology Hellas (CERTH), \\ Maroussi, 15125 Athens, Greece; koukouzas@certh.gr \\ 3 Department of Industrial Design and Production Engineering, University of West Attica, \\ Gr-12244 Egaleo, Greece; nikolaos.laskaris@gmail.com \\ 4 Department of Geology and Geoenvironment, National and Kapodistrian University of Athens, \\ Panepistimioupolis Zografou, 15784 Athens, Greece; ppomonis@geol.uoa.gr \\ * Correspondence: Geo.plan@outlook.com
}

Received: 19 February 2020; Accepted: 23 April 2020; Published: 3 May 2020

\begin{abstract}
We investigate with this study the effectiveness of mechanically activated serpentinite in capturing $\mathrm{Cu}$ (II) from the multi-constituent acidic wastewater of the pit lakes of the Agios Philippos mine (Greece), proposing specific areas with serpentinites suitable for such environmental applications. For this purpose ultramafic rock samples that are characterized by variable degrees of serpentinization from ophiolitic outcrops exposed in the regions of Veria-Naousa and Edessa have been examined regarding their capacity to remove the toxic load of $\mathrm{Cu}$ (II) from wastewater after having been mechanically activated through a Los Angeles (LA) machine (500, 1000 and 1500 revolutions). The more serpentinized and mechanically activated samples, as they have been characterized after a combination of various mineralogical, petrographic, geochemical analyses as well as after different stresses of abrasion and attrition, seem to be more effective in $\mathrm{Cu}$ removal than the less serpentinized ones. Selective removal of $\mathrm{Cu}$ (II) in the wroewolfeite phase was obtained by using the mechanically activated highly serpentinized ultramafic rocks. Furthermore, areas with highly serpentinized ultramafic rocks defined after petrographic mapping, using GIS method, which can potentially be used as filters for the effective $\mathrm{Cu}$ (II) removal from industrial wastewater are suggested.
\end{abstract}

Keywords: removal of $\mathrm{Cu}$; mechanical activation of serpentinite; sustainability; wastewater treatment

\section{Introduction}

Today, societies are vastly affected by negative changes in the quality of water, air, and soil as a result of human activities. More specifically, large volumes of wastewater present within lakes, river or in industries, put intense pressure on mankind. Among the different types of pollutants, non-organic ones have a high-risk factor and are characterized as being harmful [1]. Mitigation of toxicity factors identified within water considered as waste that has been produced by industrial activities is a main concern in modern-day societies. Wastewater produced from industrial and human activities, must be brought back the societies as well as to Nature, which includes rivers, lakes and land [2]. More specifically, acidic drainage or pit lakes produced by past mining activities are held as being 
responsible for numerous problems associated with degraded water quality of which is responsible for limited access to water, especially for people living in surrounding regions with high poverty rates, raising risk factors for both conflicts and environmental reduction potentials for natural regeneration processes to occur [3-6]. Pit lakes are often acidic ( $\mathrm{pH} 2-3)$, containing elevated concentrations of metals and metalloids showing a potential for the formation of highly acidic conditions, due to the fact that they exhibit relatively low buffer capacity levels [7-9]. Heavy metals are considered as high risk pollutants which are present in wastewater, including those originated from mining operations and industries which produce plants, batteries, paints and pigments, which also include industries that produce glass and ceramic materials. Wastewater often incorporates elements such as $\mathrm{Cr}, \mathrm{Pb}, \mathrm{Cd}, \mathrm{Zn}$, $\mathrm{Cu}$ and $\mathrm{Ni}$ [9]. When these metals are exposed to the environmental conditions, it is observed that ions are accumulated within humans, a process that will take place by consumption in the whole food chain cycle, thereby creating toxic concentrations of metals characterized as heavy that must not reach the environment [10].

Several applications have been proposed to achieve the removal of the toxic load, which include coagulation, chemical precipitation, filtration, ion exchange and solvent extraction, as well as enablement of evaporation and membrane methodologies [11]. Adsorption of heavy metals can be realized with conventional materials such as activated carbon which is often used effectively in various applications and also the use of carbon formed by organic materials (carbonized). Low cost carbon-containing materials have been used for the adsorption of inorganic pollutant materials and the removal of heavy metals, such as agricultural wastes (wool, rice, rice hulls, peat moss, cork biomass, untreated coffee grounds), modified biopolymers and industrial by-products [12,13]. Recent studies $[14,15]$ state that peat can be regarded as highly effective in removing several heavy metals (like $\mathrm{Hg}$ ) derived from water solutions by the performance of two types of experiments (batch and column). Peat produced by sphagnum plant moss accumulation is very effective at absorbing and removing Cd hypochlorite and oxidized $\mathrm{Cd}(\mathrm{CN})_{2}$ plant waste, $\mathrm{Cr}^{6+}$ derived from aqueous solutions, and also $\mathrm{Pb}, \mathrm{Ni}, \mathrm{Cu}, \mathrm{Zn}$ and $\mathrm{Cd}$ from waters considered as waste [16-19]. Biochar can be formed from various sources that include, for example: straw, shells, crop residues, wood, stover, bark, rubber, sludge, litter and peat [20-23]. Biochars produced from peat moss using pyrolysis procedures with variable carbonization conditions have raised research interest for heavy metal adsorption [24].

Numerous researchers have mentioned the use of many different rock lithotypes that include dolomite, magnesite, limestone, andesite, serpentinite and dunite not only in order to increase the $\mathrm{pH}$ value of industrial wastewater but also to capture heavy metals such as $\mathrm{Cu}[25,26]$. Most of the aforementioned rock types are broadly used combined with other rocks as aggregate materials in a large number of construction and industrial applications while producing a vast number of sterile materials [27]. Therefore, it is important to investigate methods in order to dispose of these sterile aggregates, in accordance with the principals of sustainability, recycling, alternative use of materials, by concurrently reducing the necessity of additional energy for mineral and rock extraction. The sustainable use of natural rocks in removing heavy metals constitutes a Nature-based self-purification function, focusing on achieving "zero wastes" and "zero emissions" goals.

Serpentinite has been used as an adsorbent of $\mathrm{Cu}$ from industrial wastewater [26] despite the fact that the risk exists for the leaching of $\mathrm{Cr}$ and $\mathrm{Ni}$. Its abundance in several ophiolite complexes, its wide range of construction and industrial applications combined with its particular textural characteristics make it particularly attractive for such applications. 
It is widely accepted by the broad scientific community that different hydrated silicate minerals and especially clay minerals (that encompass serpentine), demonstrate abilities in the adsorption of undesirable heavy metal elements. Serpentine constitutes a group of high-Mg 1:1 layered trioctahedral minerals, with its structural formula being $\mathrm{Mg}_{6}\left(\mathrm{Si}_{4} \mathrm{O}_{10}\right)(\mathrm{OH})_{8}$. It is characterized as chemically simple but from the view of texture can be present in various forms. The serpentine mineral group occurs in three polymorphs: the high pressure antigorite and the low pressure chrysotile and lizardite. Lizardite in particular displays an ideal layered topology and on the other hand chrysotile has a bent structure and antigorite is often modulated [28,29]. Serpentine polymorphs belong to the phyllosilicate mineral group that displays a 1:1 layered structure, which comprises tetrahedral and octahedral sheets [28]. Four distinct $\mathrm{O}-\mathrm{H}$ chain groups were identified in serpentine minerals. These are classified into two distinct topologies based on their $(\mathrm{OH})$ positioning. Three of the four $\mathrm{O}-\mathrm{H}$ groups are situated on the inner surface amongst two layers, whereas the third is located within the layer. The primitive unit serpentinite cell is held responsible for the cohesive attachment of the two successive layers that form hydrogen bonds $[28,30]$.

When serpentinite is attached through the application of mechanical force activation (e.g., ball impact), this results in structural changes that mostly affect the $\mathrm{OH}$ groups that could potentially be brought to a looser state in the octahedral positions, enhancing the dispersal of the latter by the effects of water. When the serpentine structure is damaged through grinding, it becomes incapable of maintaining atom arrangements in a proper order to preserve its crystallinity. Scientists like Huang [31] have used activated serpentine in order to remove $\mathrm{Cu}$ from wastewater. The raw serpentine without grinding operation adsorbs less $\mathrm{Cu}$ than the chemo-mechanically-activated serpentine.

The aim of this study is the selective capture of $\mathrm{Cu}$ (II) within the crystalline structure of serpentine from tmechanically activated serpentinized ultramafic rocks from the acidic wastewater of a pit lake of the Agios Philippos mine (Greece). The suggestion of specific areas in Greece that present serpentinized ultramafic rocks suitable for $\mathrm{Cu}$ capture is a supplementary goal of this study.

\section{Geological Description of Rock Materials Sources}

Representative serpentinized rocks deriving from the Veria-Naousa and Edessa ophiolite complex (Greece) have been selected for studying their effectiveness in the removal of $\mathrm{Cu}$ from industrial wastewater after having been mechanically activated. The Veria-Naousa ophiolite belongs to the Almopias subzone (Axios geotectonic zone) in northern Greece. Its sequence consists of intense and highly tectonized serpentinized lherzolite and harzburgite of $46.76 \mathrm{~km}^{2}$ total surface area (calculated via ArcMap 10.1), penetrated by scarce pyroxenitic dykes [32], and from gabbro, diabase and pillow basalt (Figure 1).

Remnants of oceanic lithosphere (Upper Jurassic to Late Cretaceous) constitute the Edessa ophiolite complex which was thrust out of one or more ocean basins [34-36]. This complex presents intense tectonization and consists of several tectonic units $[37,38]$ such as serpentinized ultramafic rocks (lherzolite and harzburgite) of $50.34 \mathrm{~km}^{2}$ total surface area (calculated via ArcMap 10.1). Moreover, diabase is the main mafic lithotype of the complex, whereas gabbro, basalt as well as diorite are less frequent (Figure 2). 

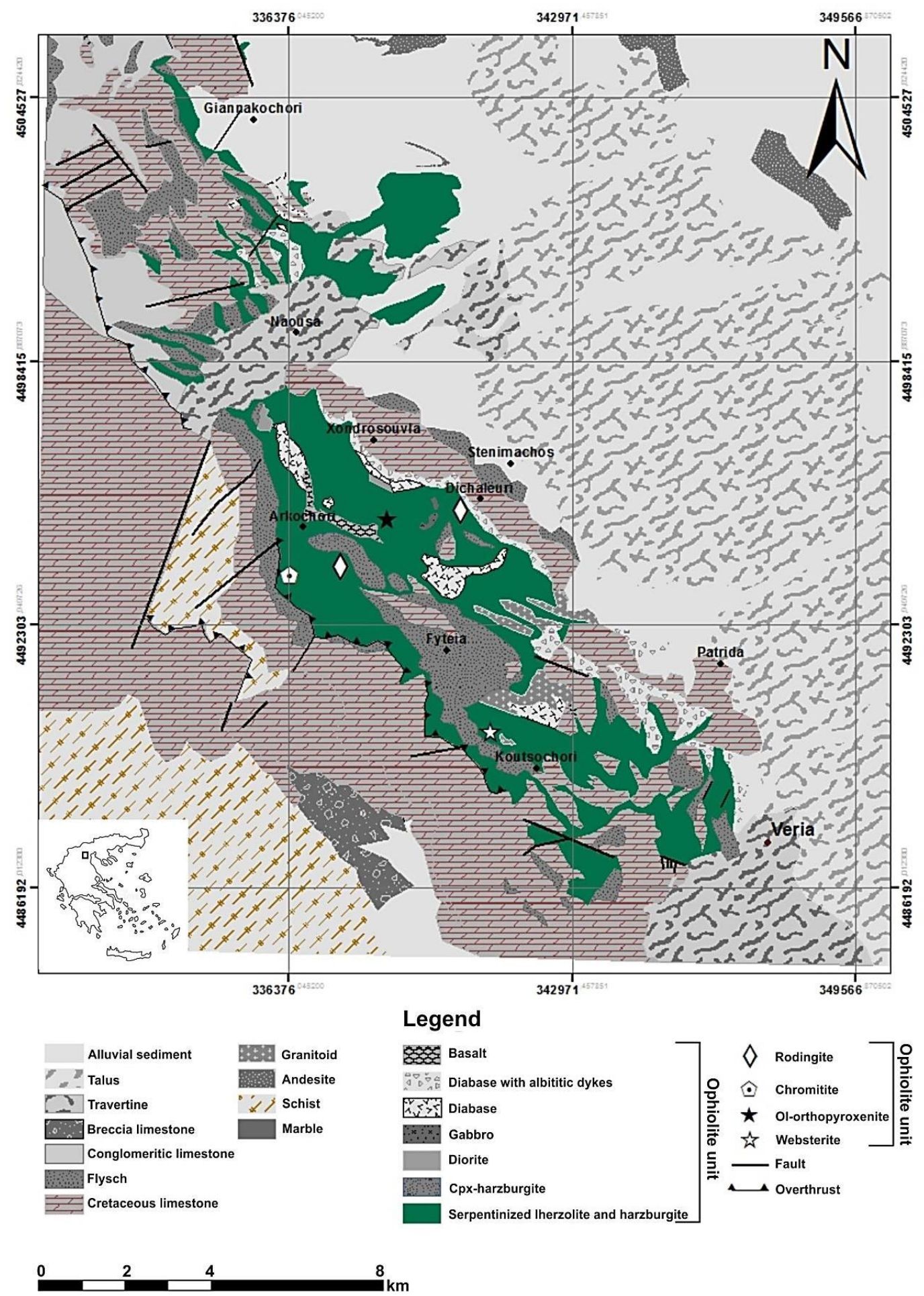

Figure 1. Modified geological map of Veria-Naousa ophiolite complex [33] after fieldwork and mapping using ArcMap 10.1; the area of investigation is shown in the black rectangle; the green color shows the serpentinized ultramafic rocks of the region. 


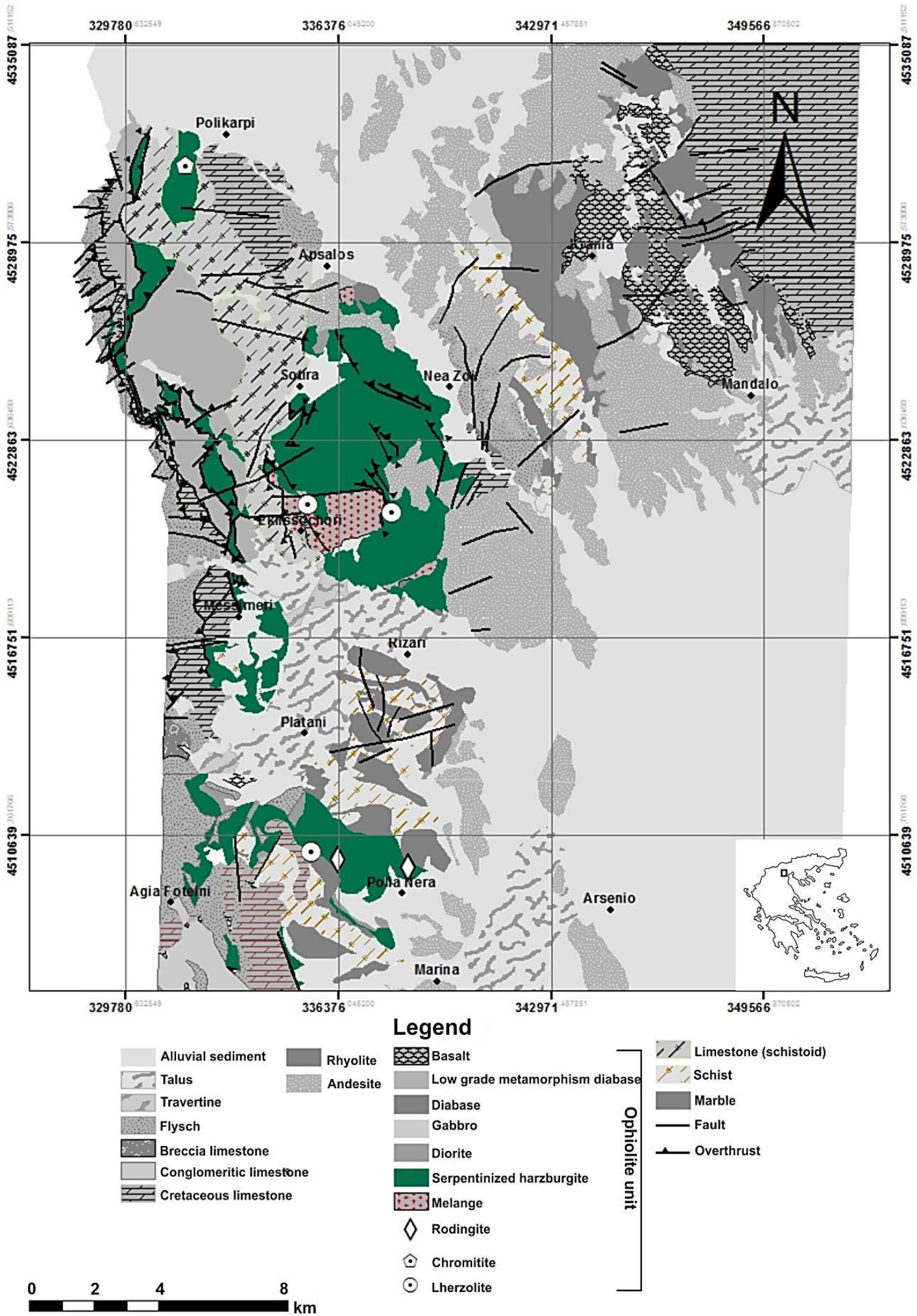

Figure 2. Modified geological map of Edessa ophiolite complex [39] after fieldwork and mapping using ArcMap 10.1; the area of investigation is shown in the black rectangle; the green color shows the serpentinized ultramafic rocks of the region. 


\section{Materials and Methods}

Taking into account how effective the serpentinite was in removing $\mathrm{Cu}$ from the wastewater from the pit lake from the Agios Phillippos Kirkis mine [26], four serpentinites, derived from the aforementioned ophiolite complexes and presenting different degree of serpentinization were used after their mechanical activation to various degrees to examine the mechanism through which serpentinite can become more effective in the removal of $\mathrm{Cu}$.

\subsection{Characterization of the Studied Rock Materials}

The first stage for the characterization of the investigated rocks is their petrographic examination (mineralogical and textural features) with the aid of a Leitz polarizing optical microscope (Leica Microsystems, Wetzlar, Germany). The modal composition of the investigated serpentinites was also identified using powder X-ray diffraction (XRPD) analysis, with a Bruker D8 Advance Diffractometer (Bruker, Billerica, MA, USA), with Ni-filtered $\mathrm{CuK} \alpha$ radiation. The scanning area for bulk mineralogy of the samples covered the $2 \theta$ interval $2-70^{\circ}$, with a scanning angle step size of $0.015^{\circ}$ and a time step of $0.1 \mathrm{~s}$. The modal composition was identified with the DIFFRACplus EVA $12^{\circledR}$ software (Bruker-AXS) based on the ICDD Powder Diffraction File of PDF-2 2006. The mineral phases were semi-quantified with the TOPAS $3.0{ }^{\circledR}$ software (TOPAS MC Inc., Oakland, CA, USA), based on the Rietveld method refinement routine. The routine is based on the calculation of a single mineral-phase pattern regarding to the crystalline structure of each mineral, and the refinement of the pattern using a non-linear least squares routine. According to the study by Bish and Post [40], the quantification errors were calculated and they are estimated to be $\sim 1 \%$. Polished thin sections of the examined rock samples were analyzed in scanning electron microscopes (SEM) in order to identify their mineralogical characteristics. Serpentine minerals microanalyses were carried out in a JEOL JSM-6300 SEM equipped with energy dispersive (EDS) using the INCA software (version). The scanning electron microscope used is located in the Laboratory of Electron Microscopy and Microanalysis (University of Patras, Greece). Operating conditions were accelerating voltage $25 \mathrm{kV}$ and beam current $3.3 \mathrm{nA}$, with a $4 \mu \mathrm{m}$ beam diameter. The total counting time was $60 \mathrm{~s}$ and dead-time $40 \%$. Synthetic oxides and natural minerals were used as standards for the analyses, where the detection limits are $\sim 0.1 \%$ and accuracy better than $5 \%$ was obtained. Furthermore, an XRF (X-Ray fluorescence) spectrometer and a sequential spectrometer (ICP-ES) were used for the determination of the major and trace elements of the studied samples, which were carried out at Bureau Veritas Mineral Laboratories (Vancouver, BC, Canada).

\subsection{Methodology for the Cu (II) Removal}

The studied serpentinites were placed in the Los Angeles (LA) machine in order to become mechanically activated after they have been sieved in the No. 14 sieve $(1.40 \mathrm{~mm})$. The Los Angeles (LA) machine is a rotating drum which contains certain number of steel spheres. Los Angeles (LA) test constitutes a basic test which indicates the mechanical quality of aggregates rocks by identifying their resistance in abrasion and attrition. At this stage, serpentinite samples were rotated in the LA machine for 500, 1000 and 1500 revolutions, respectively. Then, the samples were sieved appropriately in order to reach the grain size of $0.8-0.6 \mathrm{~mm}$ which then used as filters in batch type columns. Serpentinites that were not mechanically activated were also used as filters in the batch type columns after having been sieved appropriately in order to reach a grain size between 0.8 and $0.6 \mathrm{~mm}$.

The next stage included an experimental arrangement consisting of columns of borosilicate glass of $20 \mathrm{~mm}$ diameter. In each column 70 gr of the different mechanically activated serpentinites (derived from the different revolutions used in the LA machine) was used, and $300 \mathrm{~mL}$ of wastewater was passed through each column four times. After this four pass procedure, wastewater samples were further processed for geochemical analysis of $\mathrm{Cu}$ concentration, which was performed in the Institute for Solid fuels Technology and Application of the National Centre for Research and Technology Hellas 
using conjugated plasma argon mass spectrometry. All the sorption experiments were carried out at room temperature $\left(25 \pm 2{ }^{\circ} \mathrm{C}\right)$.

\section{Results}

\subsection{Results of the Studied Rock Materials}

\subsubsection{Petrographic Features of the Studied Rock Materials}

Two types of serpentinized ultramafic rocks regarding their degree of serpentinization were collected from the studied areas. Their textural and mineralogical characteristics are analyzed below in Figure 3.
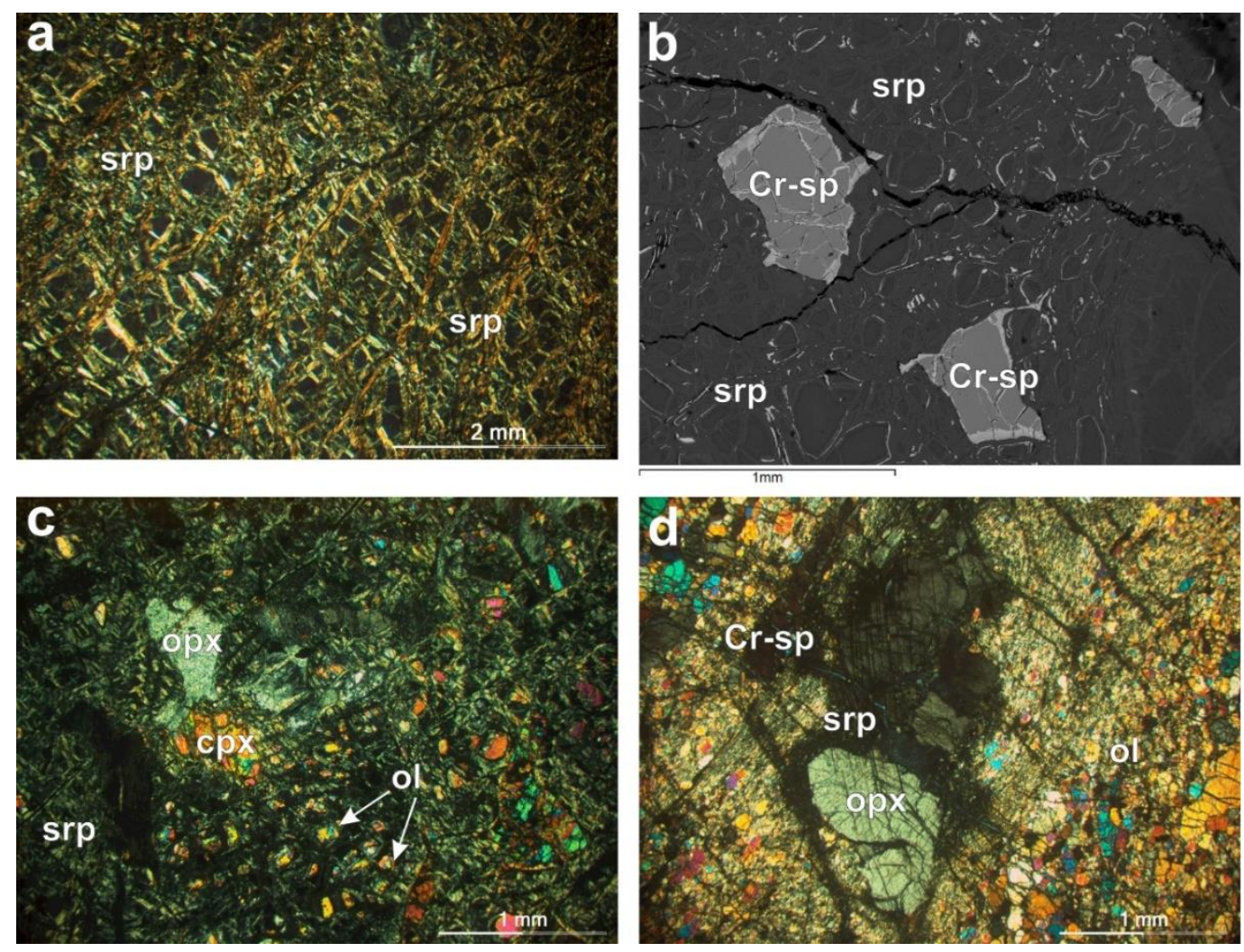

Figure 3. Textural features of serpentinites from the investigated ophiolite complexes: (a) Photomicrograph of mesh texture in serpentinized (srp) matrix (sample BE.01, + Nicols); (b) Back-scattered electron image (BSE) of Cr-spinel (Cr-sp) with curved boundaries and thin rims of ferritchromit and magnetite as well as mesh serpentine (srp) (sample ED.111); (c) Photomicrograph of an orthopyroxene (opx) porphyroclast and clinopyroxene porphyroclast (cpx) surrounded by olivine neoblasts (ol) in serpentinized (srp) matrix (sample BE.118, + Nicols); (d) Photomicrograph of orthopyroxene porphyroclast (opx) and olivine grains (ol), subhedral Cr-spinel (Cr-sp) and ribbon serpentine (srp) (sample ED.86B, + Nicols).

\section{(1) Highly-serpentinized (Group I)}

The primary modal mineralogical assemblage of the highly serpentinized ultramafic rocks is intensely altered, whereas relics of orthopyroxene and Cr-spinel were observed. The subhedral to euhedral Cr-spinel are frequently crosscut by secondary veins and/or surrounded by thin rims of magnetite and ferritchromit because of the effects of ocean floor alteration processes. Serpentine is the main alteration phase which forms mesh, ribbon, bastite and hourglass textures. Moreover, less chlorite and magnetite subsequently observe, likely being the result of retrograde metamorphism during exhumation (Figure 3). 
(2) Medium-Serpentinized (Group II)

The primary assemblage of these serpentinized ultramafic rocks comprises of orthopyroxene, olivine, less of clinopyroxene, olivine and Cr-spinel constituting less than $30 \%$ of the whole assemblage. Porphyroclasts of orthopyroxene exhibit exsolution lamellae of clinopyroxene, typical characteristic of mantle peridotites. Olivine displays porphyroclastic grains and smaller neoblasts. Locally, olivine porphyroclasts show strain lamellae, undulose extinction, shearing and recrystallization (Figure 3). Clinopyroxene appears as relict subhedral porphyroclasts. Crystals of $\mathrm{Cr}$-spinel presented as subhedral to euhedral and they display an irregular distribution of ferritchromit compositional areas. The boundary between the Cr-spinel (either unaltered or altered) and the ferritchromit is curved and lobate. The main secondary product is serpentine which predominantly displays ribbon and mesh textures, whereas others are chlorite and magnetite. The modal composition of the investigated serpentinites was further determined by XRPD analysis in Figure 4 .
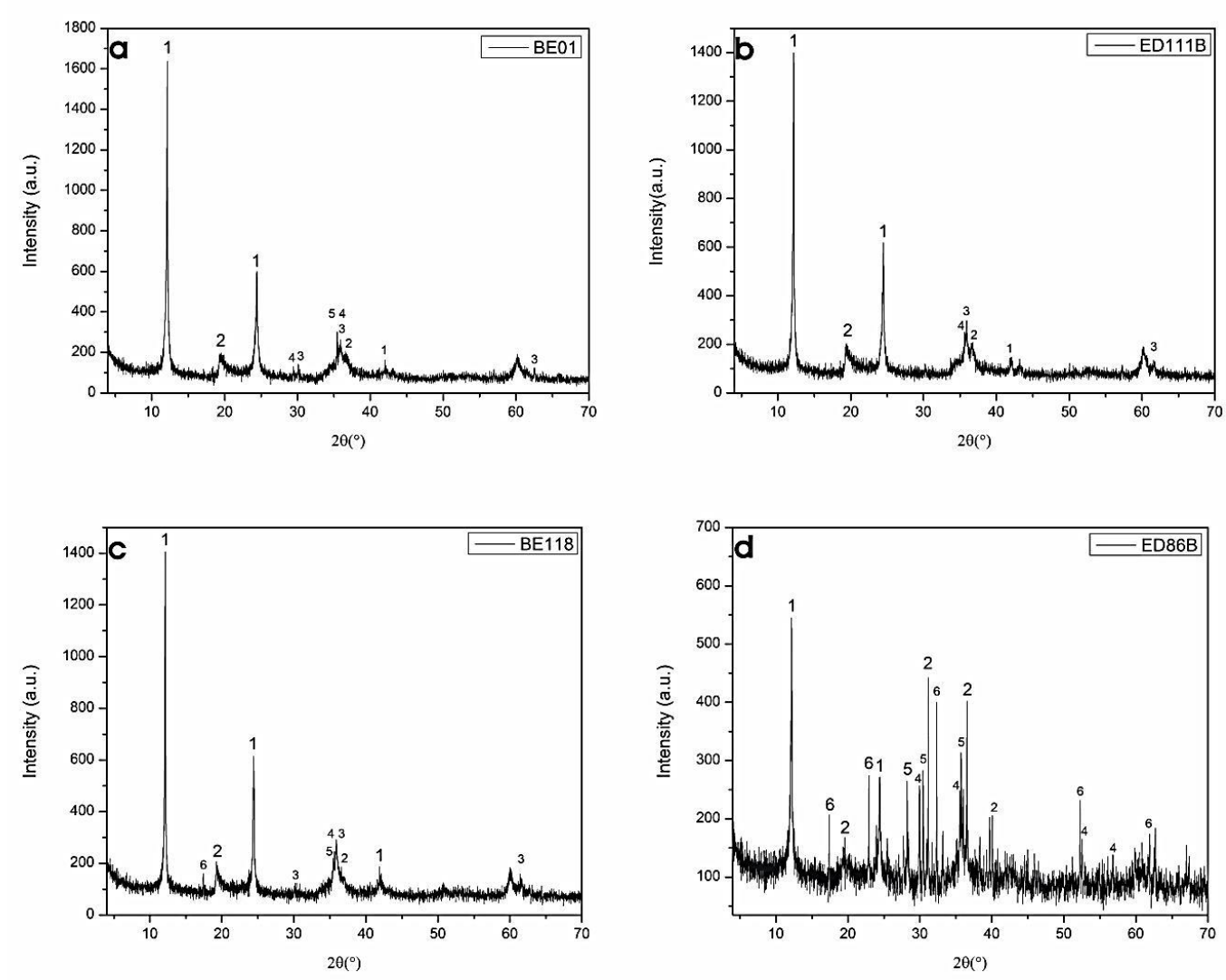

Figure 4. XRPD patterns of the examined serpentinites: (a) highly serpentinized ultramafic rock (sample: BE.01); (b) highly serpentinized ultramafic rock (sample: ED.111B); (c) medium serpentinized ultramafic rock (sample: BE.118); (d) medium serpentinized ultramafic rock (sample: ED.86B), (1: Serpentine, 2: Spinel, 3: Magnetite, 4: Clinopyroxene, 5: Orthopyroxene, 6: Olivine).

\subsubsection{XRPD of Mineral Rock Materials}

The X-ray diffraction enabled us to identify the crystalline phases of the tested ultramafic rocks where higher picks of serpentine were observed in samples BE.01 and ED.111B whereas samples BE.118 and ED.86B display lower picks of serpentine (Figure 4). Serpentine content as well the content of other mineralogical phases of the studied rock samples were calculated via Rietveld method and are listed in the Table 1, where the sample BE.01 presents as the most serpentinized, while ED.86B presents as the less serpentinized sample. The identification of the degree of serpentinization of the studied rock samples through the petrographic analysis via polarizing microscope is in accordance with the results of Rietveld method. 
Table 1. Semi-quantitative mineralogical assemblage of the tested serpentinites. The quantification errors calculated for each phase according to Bish and Post [40] are estimated to be $\sim 1 \%$ (ol: olivine, opx: orthopyroxene, cpx: clinopyroxene, sp: spinel, mgt: magnetite, srp: serpentine, BE: Veria-Naousa ophiolite, ED: Edessa ophiolite) (-: below detection limit).

\begin{tabular}{ccccccc}
\hline Samples & ol & opx & cpx & sp & mgt & srp \\
\hline BE.01 & - & 2.3 & 1.7 & 3.3 & 1.0 & 91.7 \\
ED.111B & - & - & 1.1 & 7.1 & 3.2 & 88.6 \\
BE.118 & 3.0 & 14.0 & 7.0 & 4.5 & 1.5 & 70.0 \\
ED.86B & 11.5 & 15.5 & 11.0 & 3.0 & - & 59.0 \\
\hline
\end{tabular}

\subsubsection{Chemistry of Serpentine Minerals}

Representative microanalyses of the serpentine minerals are shown in Table 2 and plotted in the diagrams of Figure 5. Serpentine minerals from Veria-Naousa and Edessa ophiolite are composed of $\mathrm{SiO}_{2}$ (42.02-46.27 wt.\%), $\mathrm{MgO}$ (36.45-41.50 wt.\%), $\mathrm{Fe}_{2} \mathrm{O}_{3}$ (1.10-6.53 wt.\%) and less $\mathrm{Al}_{2} \mathrm{O}_{3}, \mathrm{CaO}$ and $\mathrm{TiO}_{2}$. Serpentine minerals from Group I display higher $\mathrm{SiO}_{2}, \mathrm{MgO}, \mathrm{Fe}_{2} \mathrm{O}_{3}$ and lower $\mathrm{Al}_{2} \mathrm{O}_{3}, \mathrm{CaO}$ and $\mathrm{TiO}_{2}$ contents than those of Group II. $\mathrm{NiO}$ and $\mathrm{Cr}_{2} \mathrm{O}_{3}$ contents are wide $(0.00-2.20$ wt.\% and 0.00-1.93 wt.\%, respectively). This wide range of $\mathrm{NiO}$ and $\mathrm{Cr}_{2} \mathrm{O}_{3}$ content may be connected with the nature of the replaced olivine in the case of Ni-rich serpentine and pyroxene as well as in the case of Cr-rich serpentine.
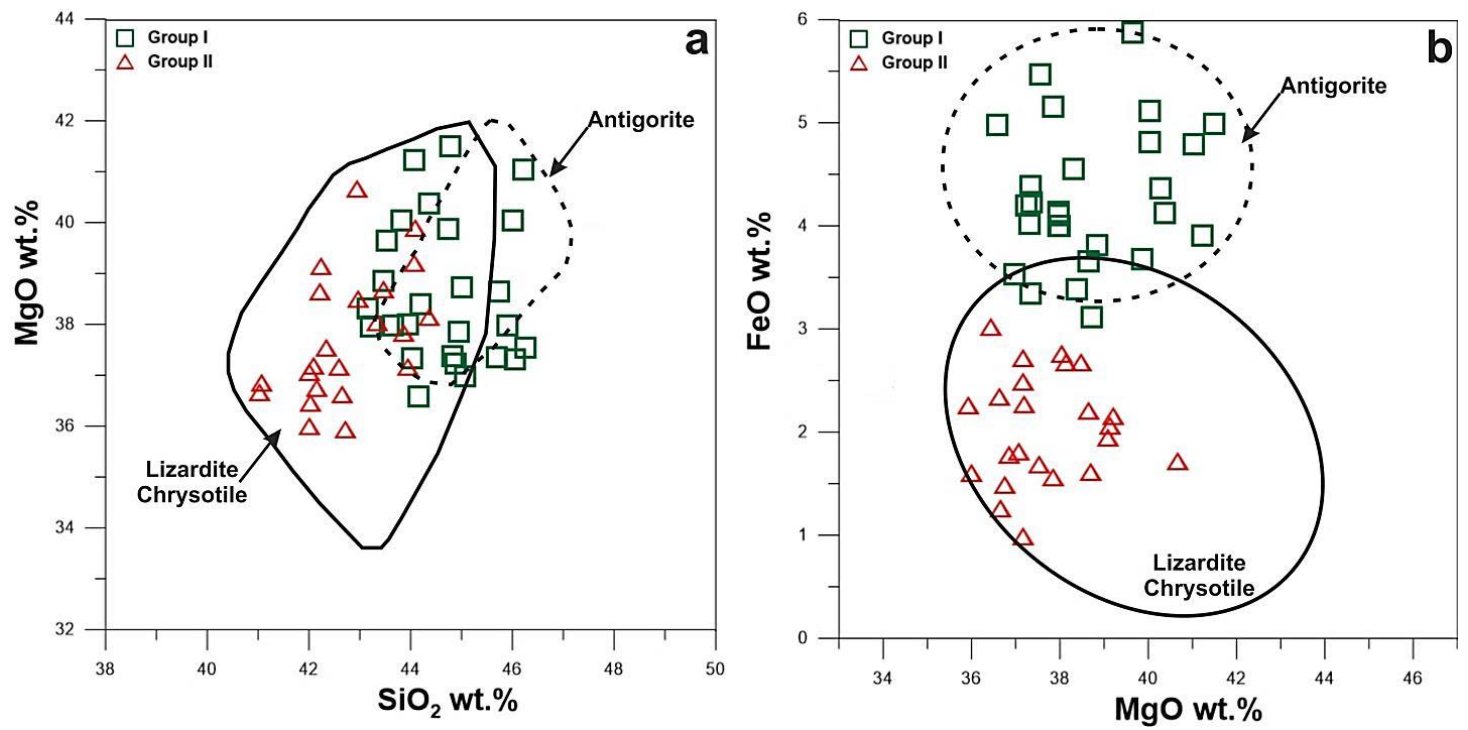

Figure 5. (a) $\mathrm{MgO}$ vs. $\mathrm{SiO}_{2}$ plot and (b) $\mathrm{FeO}$ vs. $\mathrm{MgO}$ plot for the analyzed serpentine minerals in serpentinites from Veria-Naousa and Edessa ophiolites. Fields of lizardite, chrysotile and antigorite are from Singh \& Singh [41]. 
Table 2. Representative electron microanalyses of serpentine minerals from serpentinites of Veria-Naousa and Edessa ophiolites (-: below detection limit).

\begin{tabular}{|c|c|c|c|c|c|c|c|c|c|c|c|c|c|c|c|c|}
\hline \multirow{3}{*}{$\begin{array}{c}\text { Sample } \\
\text { Anal. } \\
\text { No }\end{array}$} & \multicolumn{8}{|c|}{ Group I } & \multicolumn{8}{|c|}{ Group II } \\
\hline & \multicolumn{4}{|c|}{ BE.01 } & \multicolumn{4}{|c|}{ ED.111B } & \multicolumn{4}{|c|}{ BE.118 } & \multicolumn{4}{|c|}{ ED.86B } \\
\hline & 14 & 18 & 21 & 23 & 3 & 7 & 10 & 14 & 7 & 13 & 17 & 20 & 4 & 5 & 8 & 10 \\
\hline \multicolumn{17}{|l|}{ wt.\% } \\
\hline $\mathrm{SiO}_{2}$ & 46.27 & 44.16 & 44.78 & 44.94 & 43.22 & 43.53 & 44.37 & 45.01 & 42.95 & 44.37 & 42.04 & 42.59 & 43.34 & 42.02 & 43.94 & 43.86 \\
\hline $\mathrm{TiO}_{2}$ & - & - & - & - & - & - & - & - & - & 0.07 & 0.09 & 0.05 & - & - & - & - \\
\hline $\mathrm{Al}_{2} \mathrm{O}_{3}$ & 0.43 & - & - & 0.22 & - & - & - & - & - & - & 0.66 & 0.96 & - & 0.70 & 1.67 & 2.58 \\
\hline $\mathrm{Fe}_{2} \mathrm{O}_{3}$ & 6.08 & 5.53 & 5.55 & 5.73 & 4.45 & 6.53 & 4.58 & 3.46 & 1.91 & 2.98 & 3.36 & 3.02 & 3.07 & 2.01 & 1.10 & 1.73 \\
\hline $\mathrm{MnO}$ & - & - & - & - & - & - & - & - & & 0.06 & - & - & - & - & - & - \\
\hline $\mathrm{MgO}$ & 37.55 & 36.58 & 41.50 & 37.85 & 37.96 & 39.65 & 40.38 & 38.72 & 40.66 & 38.14 & 36.45 & 37.17 & 38.05 & 37.06 & 37.17 & 37.84 \\
\hline $\mathrm{CaO}$ & - & - & - & - & - & - & - & - & 0.18 & 0.08 & - & 0.14 & - & - & 0.08 & 0.19 \\
\hline $\mathrm{Na}_{2} \mathrm{O}$ & - & - & - & - & - & - & - & - & - & - & - & 0.06 & - & - & - & - \\
\hline $\mathrm{K}_{2} \mathrm{O}$ & - & - & - & - & - & - & - & - & - & - & - & - & - & - & - & - \\
\hline $\mathrm{NiO}$ & - & - & - & - & - & - & - & - & - & - & - & - & 2.20 & - & 0.39 & 0.45 \\
\hline $\mathrm{Cr}_{2} \mathrm{O}_{3}$ & 0.39 & - & - & - & 0.81 & - & - & - & - & 0.05 & - & - & - & 0.64 & 1.35 & 1.93 \\
\hline Sum & 90.72 & 86.27 & 91.83 & 88.74 & 86.44 & 89.71 & 89.33 & 87.19 & 85.70 & 85.75 & 82.60 & 83.99 & 86.66 & 82.43 & 85.70 & 88.58 \\
\hline \multicolumn{17}{|c|}{ Formula units based on 7 atoms of oxygens } \\
\hline $\mathrm{Si}$ & 2.068 & 2.073 & 1.988 & 2.054 & 2.030 & 1.985 & 2.015 & 2.078 & 2.020 & 2.081 & 2.051 & 2.042 & 2.041 & 2.049 & 2.058 & 2.000 \\
\hline $\mathrm{Ti}$ & - & - & - & - & - & - & - & - & - & 0.002 & 0.003 & 0.002 & - & - & - & - \\
\hline $\mathrm{Al}$ & 0.023 & - & - & 0.012 & - & - & - & - & - & - & 0.038 & 0.054 & - & 0.040 & 0.092 & 0.139 \\
\hline $\mathrm{Fe}^{3+}$ & 0.205 & 0.195 & 0.185 & 0.197 & 0.157 & 0.224 & 0.157 & 0.120 & 0.068 & 0.105 & 0.123 & 0.109 & 0.109 & 0.074 & 0.039 & 0.059 \\
\hline $\mathrm{Mn}$ & - & - & - & - & - & - & - & - & - & 0.002 & - & - & - & - & - & - \\
\hline $\mathrm{Mg}$ & 2.502 & 2.560 & 2.746 & 2.579 & 2.658 & 2.695 & 2.734 & 2.664 & 2.850 & 2.666 & 2.650 & 2.657 & 2.671 & 2.694 & 2.595 & 2.572 \\
\hline $\mathrm{Ca}$ & - & - & - & - & - & - & - & - & 0.009 & 0.004 & - & 0.007 & - & - & 0.004 & 0.009 \\
\hline $\mathrm{Na}$ & - & - & - & - & - & - & - & - & - & - & - & 0.006 & - & - & - & - \\
\hline $\mathrm{K}$ & - & - & - & - & - & - & - & - & - & - & - & - & - & - & - & - \\
\hline $\mathrm{Ni}$ & - & - & - & - & - & - & - & - & - & - & - & - & 0.083 & - & 0.015 & 0.017 \\
\hline $\mathrm{Cr}$ & 0.014 & - & - & - & 0.030 & - & - & - & - & 0.002 & - & - & - & 0.025 & 0.050 & 0.070 \\
\hline Total & 4.811 & 4.829 & 4.919 & 4.842 & 4.876 & 4.903 & 4.906 & 4.862 & 4.947 & 4.863 & 4.866 & 4.877 & 4.905 & 4.882 & 4.852 & 4.866 \\
\hline
\end{tabular}


In the diagram of Figure 5a, the analyzed serpentine minerals from Group I are mostly antigorite, while Group II are mostly lizardite and chrysotile and less antigorite. The similarity in characteristics is consistent with the plot of $\mathrm{MgO}$ vs. $\mathrm{FeO}$ (Figure $5 b$ ). $\mathrm{FeO}$ was calculated by the $\mathrm{Fe}_{2} \mathrm{O}_{3}$ method in order produce the diagram shown in Figure $5 b$.

\subsubsection{Geochemical Features of Rock Materials}

Major and trace elements data from the studied serpentinites, along with their loss on ignition (LOI) values are listed in Table 3. LOI values vary significantly from $7.9 \%$ to $14.6 \%$ with the most serpentinized sample (BE.01) presenting the higher LOI value, while the least serpentinized one (ED.86B) presenting the lowest LOI value.

Table 3. Representative geochemical analyses of the studied serpentinites (-: below detection limit, total).

\begin{tabular}{ccccc}
\hline \multicolumn{5}{c}{ Group I } \\
\hline Sample & BE.01 & ED.111B & BE.118 & ED.86B \\
\hline \multicolumn{5}{c}{ Major elements (wt. \%) } \\
$\mathrm{SiO}_{2}$ & 39.82 & 40.21 & 40.17 & 42.01 \\
$\mathrm{TiO}_{2}$ & - & - & 0.01 & 0.13 \\
$\mathrm{Al}_{2} \mathrm{O}_{3}$ & 1.01 & 0.44 & 1.48 & 3.57 \\
$\mathrm{Fe}_{2} \mathrm{O}_{3}$ & 8.86 & 8.89 & 7.43 & 8.06 \\
$\mathrm{MnO}$ & 0.11 & 0.06 & 0.12 & 0.11 \\
$\mathrm{MgO}$ & 34.17 & 33.54 & 36.28 & 34.17 \\
$\mathrm{CaO}$ & 0.10 & 0.16 & 1.46 & 3.17 \\
$\mathrm{Na}{ }_{2} \mathrm{O}$ & - & - & - & 0.18 \\
$\mathrm{~K}_{2} \mathrm{O}$ & - & - & - & - \\
$\mathrm{P}_{2} \mathrm{O} 5$ & - & - & 0.01 & 0.02 \\
$\mathrm{LOI}$ & 14.6 & 14.0 & 12.4 & 7.9 \\
$\mathrm{Total}$ & 98.67 & 99.30 & 99.36 & 99.32 \\
\hline \multicolumn{5}{c}{ Trace elements (ppm) } \\
$\mathrm{Cr}$ & 2963 & 2333 & 2292 & \\
$\mathrm{Co}$ & 91.1 & 88.4 & 100.7 & 2607 \\
$\mathrm{Ni}$ & 2655.8 & 2958.7 & 2185.0 & 1812.9 \\
$\mathrm{Cu}$ & 12.9 & 8.2 & 5.8 & 5.1 \\
$\mathrm{Zn}$ & 8 & 30 & 24 & 15 \\
$\mathrm{~Pb}$ & 21.7 & 0.8 & 0.6 & 0.3 \\
$\mathrm{As}$ & 7.2 & 2.6 & - & - \\
$\mathrm{U}$ & 0.2 & 3.0 & - & - \\
\hline
\end{tabular}

\subsection{Experimental Study Results}

\subsubsection{Chemical Analysis of the Wastewater}

The wastewater from the selected pit lake of the Agios Philippos mine is characterized by an acidic $\mathrm{pH}$ value (2.99) and was geochemically analyzed by Petrounias et al. [26]. These results are given in Table 4. According to the results of Table 4, the wastewater contains an extremely high concentration of $\mathrm{Cu}(8847.21 \mathrm{ppb})$. 
Table 4. Chemical analysis of wastewater (-: below detection limit) [26].

\begin{tabular}{cc}
\hline Elements (ppb) & Concentrations \\
\hline $\mathrm{Ag}$ & 0.18 \\
$\mathrm{As}$ & - \\
$\mathrm{Ba}$ & 20.54 \\
$\mathrm{Be}$ & 24.11 \\
$\mathrm{Cd}$ & 1717.73 \\
$\mathrm{Co}$ & 213.11 \\
$\mathrm{Cr}$ & - \\
$\mathrm{Cs}$ & 13.70 \\
$\mathrm{Cu}$ & 8847.21 \\
$\mathrm{Ga}$ & 3.90 \\
$\mathrm{Li}$ & 25.96 \\
$\mathrm{Mn}$ & $70,982.00$ \\
$\mathrm{~Pb}$ & 812.77 \\
$\mathrm{Rb}$ & 60.42 \\
$\mathrm{Sr}$ & 520.57 \\
$\mathrm{~V}$ & - \\
$\mathrm{U}$ & 111.96 \\
$\mathrm{Zn}$ & $285,458.55$ \\
$\mathrm{Se}$ & 24.91 \\
$\mathrm{Ni}$ & 1149.40 \\
$\mathrm{Fe}$ & 6149.02 \\
\hline
\end{tabular}

4.2.2. Chemical Analysis of Wastewater after Having Penetrated 4 Times through Columns of Batch Type

Table 5 displays the final results of the chemical analyses of wastewater after having been passed four times through each column, in which the different mechanically activated serpentinites were used as filters. As displayed in Table 5, high amounts of $\mathrm{Cu}$ have been trapped from the samples that contain higher serpentinite contents.

Table 5. Chemical analysis of the wastewater.

\begin{tabular}{ccccc}
\hline & \multicolumn{5}{c}{$\mathbf{C u}(\mathbf{p p b})$} \\
\hline Samples/Revolutions & $\mathbf{0}$ & $\mathbf{5 0 0}$ & $\mathbf{1 0 0 0}$ & $\mathbf{1 5 0 0}$ \\
\hline BE.01 & 4563.20 & 80.35 & 65.40 & 25.21 \\
ED.111B & 6380.51 & 121.30 & 85.47 & 35.30 \\
BE.118 & 7500.46 & 3670.40 & 1670.40 & 320.48 \\
ED.86B & 8070.31 & 6120.00 & 2720.50 & 670.12 \\
\hline
\end{tabular}

More specifically, the highly serpentinized sample (BE.01) seems to present a higher $\mathrm{Cu}$ removal capacity in comparison to the other three rock samples, even when used without having been mechanically activated, as well as when it was mechanically activated after 500, 1000 and 1500 revolutions, respectively.

\subsubsection{Chemical X-ray Diffractometry of Serpentinites after the Experimental Study}

The mechanically activated serpentinites (after 1500 revolutions), after having been used as filters in the experimental arrangement of the batch type columns for the removal of $\mathrm{Cu}$, were analyzed by X-ray diffractometry. The corresponding X-ray diffraction patterns are given in Figure 6. In the pattern of samples BE.01 and of ED.111B, which are the most serpentinized, the mineral wroewolfeite $\left[\mathrm{Cu}_{4}\left(\mathrm{SO}_{4}\right)(\mathrm{OH})_{6} 2 \mathrm{H}_{2} \mathrm{O}\right]$ appears, in contrast to the other two samples which are characterized by lower serpentinite contents (samples BE.118 and ED.86B). 

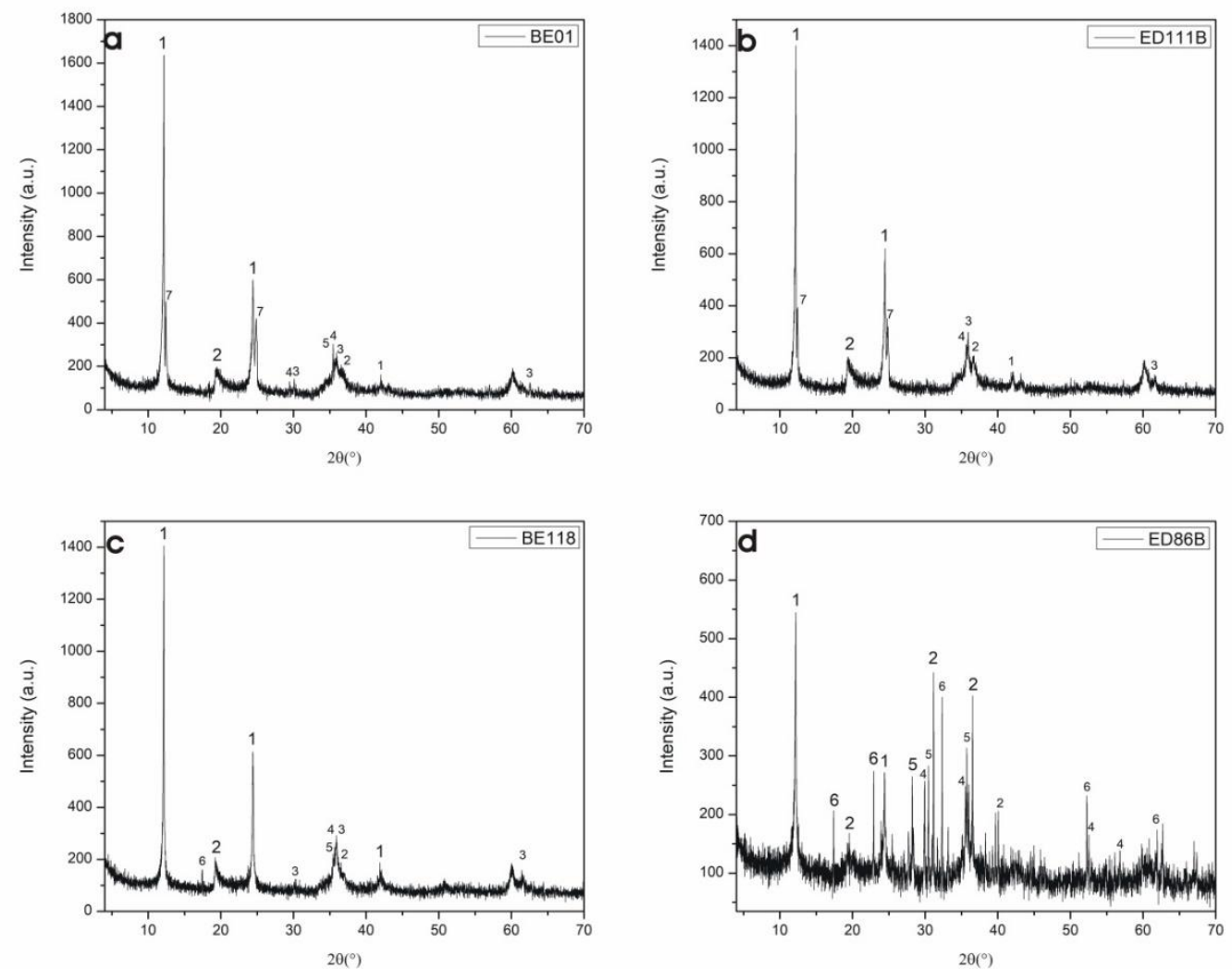

Figure 6. XRPD patterns of the investigated serpentinites: (a) highly serpentinized ultramafic rock (sample: BE.01); (b) highly serpentinized ultramafic rock (sample: ED.111B); (c) medium serpentinized ultramafic rock (sample: BE.118); (d) medium serpentinized ultramafic rock (sample: ED.86B), (1: Serpentine, 2: Spinel, 3: Magnetite, 4: Clinopyroxene, 5: Orthopyroxene, 6: Olivine, 7: Wroewolfeite).

\section{Discussion}

Several researchers have studied the individual use of minerals and of rocks materials in various environmental applications and more specifically for the removal of toxic loads using these materials $[25,26]$. Furthermore, quite many researchers have carried out mechanical, chemical and mechanochemical activation of minerals and rocks in order to increase their effectiveness in removing toxic loads from wastewater. Huang et al. [31] have concluded that mechanochemically activated serpentine presents very satisfactory results concerning $\mathrm{Cu}$ (II) removal (to an almost complete degree), allowing this type of removal to act as a way/method of recycling and reusing $\mathrm{Cu}$ derived from various wastewater solutions. Mechanical activation constitutes a way of applying mechanical stress to induce changes in the surface properties as well as in the crystalline structure of minerals [42-45]. Even though numerous studies relative to the understanding of the nature of the effect of mechanical loads on structural changes in the structure of minerals have been carried out, the activation of low cost phyllosilicate minerals, such as serpentine, has not yet been extensively investigated in environmental metal neutralization uses.

Petrounias et al. [26] combined sterile raw materials by using sterile aggregates of the LA test, and achieved significant removal of $\mathrm{Cu}$ from the Agios Philippos Kirkis mine (Greece). They attributed the $\mathrm{Cu}$ removal to the existence of mechanically activated serpentinite. This was carried out under $\mathrm{pH} 4$ conditions, where precipitation of metal complexes is not favored [46]. In general, the $\mathrm{pH}$ of the solution controls the adsorption of $\mathrm{Cu}$ in the laminated serpentine, mainly of tetrahedral silicate during the ion exchange process.

This study, which is based on and expands the initial study of Petrounias et al. [26] attempted to find out, more accurately, the mechanism as well as the necessary and sufficient conditions for a 
serpentinized ultramafic rock to work efficiently in selective $\mathrm{Cu}$ capture from wastewater. As presented in Table 5, it is obvious that as the mechanical stress increases (through the LA test), which means that as the loadings of abrasion and attrition increase, the capacity of the serpentinized rocks in capture $\mathrm{Cu}$ increases regardless their degree of serpentinization. Thus, this increase may happen exclusively due to the existence and the structure of serpentine. When serpentine is subjected to mechanical loading there is structural change, especially in the $\mathrm{OH}^{-}$group, which may become more relaxed than in the octahedral positions and easily circulate in solution when in contact with it [31]. When the structure of serpentine is decomposed by the use of abrasive mechanical stresses, is is unable to retain its atom structure and thus its crystallinity is altered. This change in the crystallinity of serpentine has been cited as one of the major factors for copper adsorption [26,31]. It is understood that mechanical stress may rupture the tetrahedral and octahedral sheets of serpentine. Moreover, intensively significant index relative to the capacity of $\mathrm{Cu}$ capture seems to be the degree of serpentinization of the rock materials used. More specifically, the more serpentinized ultramafic rocks (BE.01, ED.111B), as they have been identified through the petrographic observation (Figure 3), the X-Ray diffractometry and Rietveld method (Figure 4, Table 1) and the geochemical analysis given through the LOI index (Table 3), seem more effective in $\mathrm{Cu}$ capture (Table 5) relative to those contained less serpentine (BE.118, ED.86B). Moreover, the effectiveness, in the $\mathrm{Cu}$ capture, of the most serpentinized ultramafic rocks is indicated by the presence of wroewolfeite in the structure of these rocks after their use as filters (Figure 6).

The amount of serpentine found in the studied rocks is presented as the determinant factor, as through this, the rate of change of available crystalline meshes capable of $\mathrm{Cu}$ capture from the studied solutions is determined. However, the combination of the abovementioned factors seems to constitute the more crucial combination concerning the effectiveness of each serpentinized lithotypes for the removal of $\mathrm{Cu}$. More specifically, the highly serpentinized ultramafic rocks (BE.01, ED.111B with $88.6-91.7 \%$ of serpentine contained) present faster and more efficient capture of $\mathrm{Cu}$ in contrast to those characterized by lesser amounts of contained serpentine (BE.118, ED.86B with 59.0-70.0\% of serpentine).

Furthermore, the $\mathrm{Cu}$ capture capacity seems to be related to the type of serpentine and therefore to the special texture characteristics of the studied serpentinites. More specifically, the serpentinized samples of similar degree of serpentinization (Table 1) but with a variety in textural features (mesh, ribbon) and in serpentine type (chrysotile, antigorite and lizardite), as shown in the corresponding diagrams (Figure 5), display significant differences regarding their $\mathrm{Cu}$ capture effectiveness. Serpentine from highly serpentinized ultramafic rocks (Group I) plotted in the field of antigorite (Figure 5) present as more capable of removing $\mathrm{Cu}$ in contrast those of Group II (medium serpentinized ultramafic rocks) whose serpentine is plotted in the field of lizardite and chrysotile. This may happen due to the different capacity of lizardite, chrysotile and antigorite for retaining their crystallinity under mechanical stress. Additionally, the petrographic characteristics such as texture may significantly influence the Cu capture. More specifically, the mesh texture of serpentine in the most serpentinized sample (BE.01) is presented as the most effective texture than the other textures of the rest studied rocks, a fact which may happen due to surface adsorption of $\mathrm{Cu}^{2+}$ when $\mathrm{CuOH}^{-}$is simultaneously generated and adsorbed within the microcells.

\section{Proposed Areas with Serpentinites for Their Potential Use as Filters for Cu Removal}

Nowadays, in the era of cyclical economy and climate change, the ability to recover and reuse metals has been studied by many researchers [31,47]. Such research is fundamental to modern cutting-edge studies. In this study, the amount of $\mathrm{Cu}$ captured using serpentinites from the Veria-Naousa and Edessa ophiolite complexes suggest promising results to potentially recover copper accumulated within the crystallinity of serpentine (Figure 6), by using a variety of physicochemical recovery methods. The main object of the this work is to capture $\mathrm{Cu}$ within the crystallinity of serpentine from serpentinized ultramafic rocks and also to examine this application in conjunction with the recovery of 
copper from wastewater, as well as to propose potential areas that encompass serpentinized ultramafic rocks suitable for these applications (Figure 7).

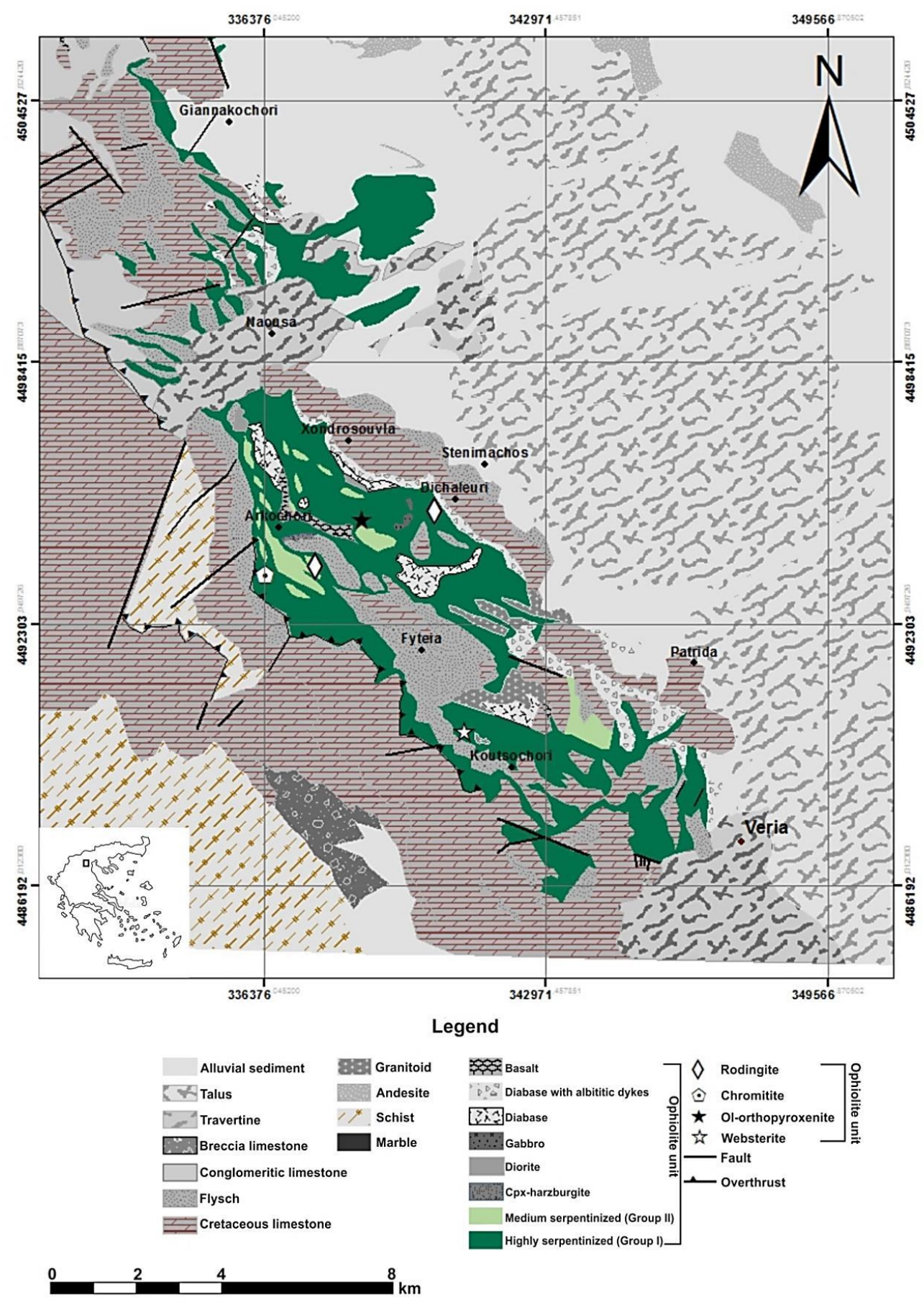

Figure 7. Modified geological map of Veria-Naousa ophiolite complex [33] after fieldwork and mapping using ArcMap 10.1; the area of investigation is shown in the black rectangle; the dark green color shows the highly-serpentinized ultramafic rocks of the region and the light green color shows the medium-serpentinized ultramafic rocks.

GIS-based petrographic mapping of serpentinites feasible to be used as raw materials for copper capture are suggested. In the modified maps (see below) we have taken into account all of the aforementioned factors and propose specific areas that are defined and measured from the examined ophiolite complexes (Figures 7 and 8). Specifically, the areas marked with dark green color (zone 
A) constitute the suggested areas from the mentioned complexes with the suitable serpentinites. These serpentinites can potentially be used as filters for $\mathrm{Cu}$ removal regarding their petrographic characteristics (degree of serpentinization, textural features and serpentine type) and geochemical characteristics (LOI index). The Veria-Naousa ophiolite complex comprises of highly-serpentinized ultramafic rocks, and GIS-based calculations yield an area of $43.84 \mathrm{~km}^{2}$, whereas the Edessa ophiolite complex is calculated to be $42.19 \mathrm{~km}^{2}$ (Figure 7). On the other hand, zone B, marked with light green color, constitutes the lesser suitable areas for $\mathrm{Cu}$ capture, as they contain lower amounts of serpentine and different mineralogical and petrographic characteristics than those of zone A.

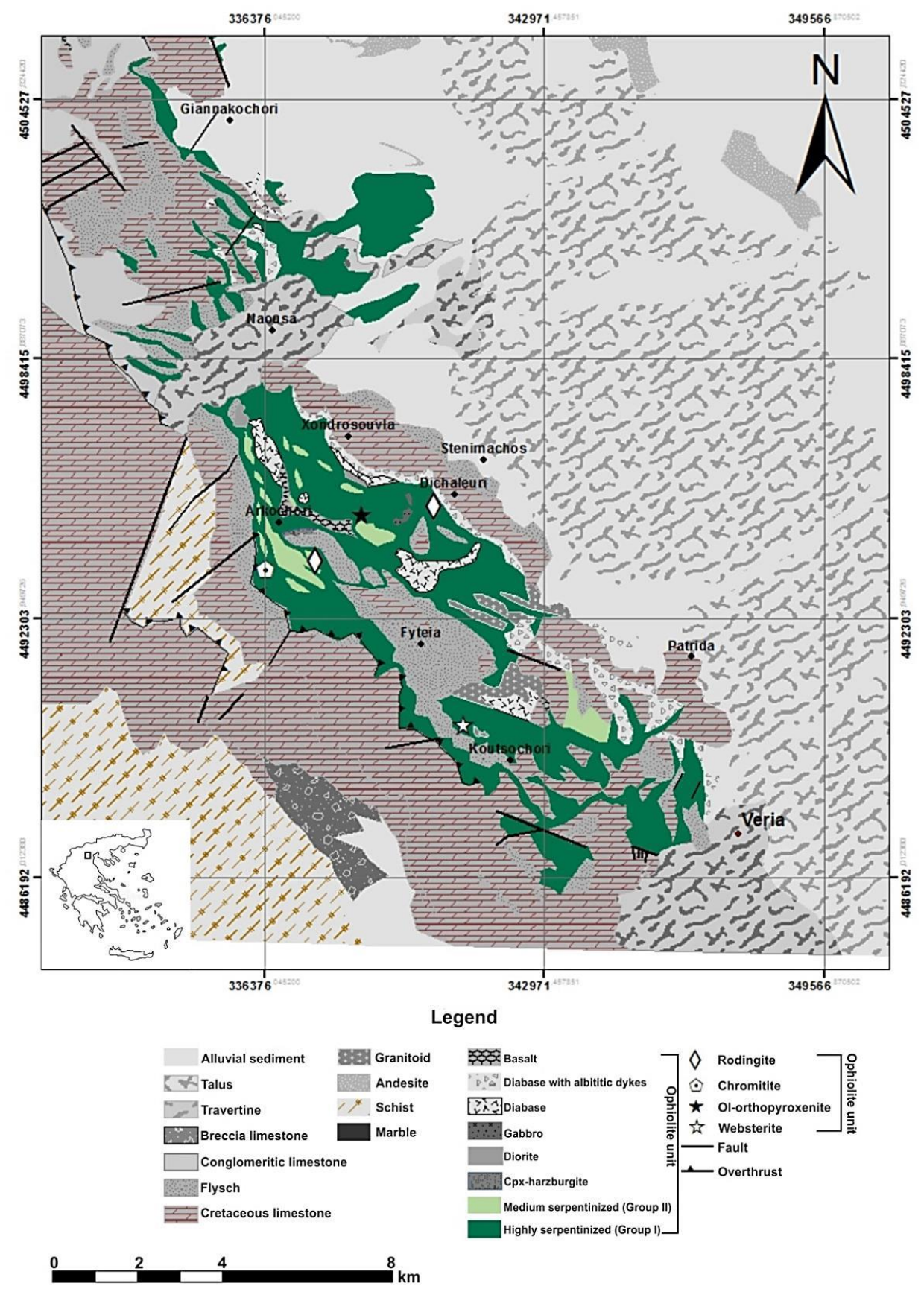

Figure 8. Modified geological map of Edessa ophiolite complex [39] after fieldwork and mapping using ArcMap 10.1; the area of investigation is shown in the black rectangle; the dark green color shows the highly-serpentinized ultramafic rocks of the region and the light green color shows the medium-serpentinized ultramafic rocks. 
Concerning the Veria-Naousa ophiolite complex, $2.93 \mathrm{~km}^{2}$ of highly serpentinized ultramafic rocks was calculated using GIS method, whereas in the Edessa ophiolite complex $8.15 \mathrm{~km}^{2}$ was calculated (Figure 8). Conclusively, the highly serpentinized ultramafic rocks from both ophiolite complexes are present in higher volumes than those of the medium-serpentinized rocks. Additionally, through the proposed maps, which are first introduced through this study, an extra use for these serpentinites is proposed apart from aggregates for construction and environmental applications as has already highlighted by Petrounias et al. [48,49].

\section{Conclusions}

In this paper, the selective capture of $\mathrm{Cu}$ (II) from acidic wastewater derived from the pit lakes of the Agios Philippos mine (Greece) from mechanically activated serpentinite using a LA machine was studied. The abovementioned study leads to the following conclusions:

- Two groups of serpentinized ultramafic rocks from the investigated ophiolite complexes which were detected according to their petrographic observations were in accordance with their mineralogical, chemical and geochemical analyses.

- The highly serpentinized rocks (Group I) are more effective in Cu removal in contrast to the medium serpentinized rock samples (Group II).

- The higher mechanical activation of the studied serpentinites (after they have been subjected to a 1500 revolutions LA test) is related to their higher capability to perform Cu removal.

- Selective removal of $\mathrm{Cu}$ (II) in the form of the wroewolfeite phase was achieved by using mechanically activated highly serpentinized ultramafic rocks.

Furthermore, areas with highly serpentinized ultramafic rocks that can potentially be used as filters for the effective $\mathrm{Cu}$ (II) removal from industrial wastewater are suggested and more specifically these are the $43.84 \mathrm{~km}^{2}$ areas from the Veria-Naousa ophiolite and the $42.19 \mathrm{~km}^{2}$ area from the Edessa ophiolite.

Author Contributions: P.P. (Petros Petrounias) participated in the fieldwork, the elaboration of laboratory tests, the interpretation of the results, coordinated the research and the writing of the manuscript; A.R. participated in the fieldwork, performed the SEM work, the interpretation of the results and contributed to the manuscript writing; P.P.G. participated in the elaboration of laboratory tests, the interpretation of the results and contributed to the manuscript writing; P.L. carried out the XRPD analyses, participated in the interpretation of the results and contributed to the manuscript writing; P.K. participated in the elaboration of laboratory tests and in the interpretation of the results; N.K. contributed to the manuscript writing; N.L. participated in the fieldwork and in the interpretation of the results; P.P. (Panagiotis Pomonis) contributed to the manuscript writing; K.H. participated in the interpretation of the results. All authors have read and agreed to the published version of the manuscript.

Funding: This research received no external funding.

Acknowledgments: We would like to thank A.K. Seferlis of the Laboratory of Electron Microscopy and Microanalysis, University of Patras for his aid, E. Gianni for her assistance in the preparation of the studied samples for laboratory tests. We also thank M. Kalpogiannaki for her assistance in the construction of the geological maps.

Conflicts of Interest: The authors declare no conflict of interest.

\section{References}

1. Ms, A.-R.; Arm, A.-R. Removal of Heavy Metals from Industrial Waste Water by Biomass-Based Materials: A Review. J. Pollut. Eff. Control. 2016, 5. [CrossRef]

2. Weber, W.J.; McGinley, P.M.; Katz, L.E. Sorption phenomena in subsurface systems: Concepts, models and effects on contaminant fate and transport. Water Res. 1991, 25, 499-528. [CrossRef]

3. Salmon, S.U.; Oldham, C.E.; Ivey, G.; Salmon, U. Assessing internal and external controls on lake water quality: Limitations on organic carbon-driven alkalinity generation in acidic pit lakes. Water Resour. Res. 2008, 44, 10414. [CrossRef]

4. Schindler, D.W. The significance of in-lake production of alkalinity. Water Air Soil Pollut. 1986, 30, 931-944. [CrossRef] 
5. Geller, W.; Klapper, H.; Salomons, W. Acidic Mining Lakes; Springer: Berlin/Heidelberg, Germany, 1998.

6. Geller, W.; Koschorreck, M.; Wendt-Potthoff, K.; Bozau, E.; Herzsprung, P.; Büttner, O.; Schultze, M. A pilot-scale field experiment for the microbial neutralization of a holomictic acidic pit lake. J. Geochem. Explor. 2009, 100, 153-159. [CrossRef]

7. Lattanzi, P.; Da Pelo, S.; Musu, E.; Atzei, D.; Elsener, B.; Fantauzzi, M.; Rossi, A. Enargite oxidation: A review. Earth-Sci. Rev. 2008, 86, 62-88. [CrossRef]

8. Sperling, E.; Grandschamp, C.A.P. Possible water uses in mining lakes: Case study of Agua Claras, Brazil. In Proceedings of the 33rd WEDC International Conference, Accra, Ghana, 7-11 April 2008; WEDC, Loughborough University: Loughborough, UK, 2008; pp. 375-380.

9. Shevenell, L.; A Connors, K.; Henry, C.D. Controls on pit lake water quality at sixteen open-pit mines in Nevada. Appl. Geochem. 1999, 14, 669-687. [CrossRef]

10. Meena, A.K.; Kadirvelu, K.; Mishra, G.; Rajagopal, C.; Nagar, P. Adsorptive removal of heavy metals from aqueous solution by treated sawdust (Acacia arabica). J. Hazard. Mater. 2008, 150, 604-611. [CrossRef]

11. Panayotova, M.; Velikov, B. Influence of zeolite transformation in a homoionic form on the removal of some heavy metal ions from wastewater. J. Environ. Sci. Health Part A 2003, 38, 545-554. [CrossRef]

12. Sekhar, K.C.; Kamala, C.; Chary, N.; Anjaneyulu, Y. Removal of heavy metals using a plant biomass with reference to environmental control. Int. J. Miner. Process. 2003, 68, 37-45. [CrossRef]

13. Babel, S.; Kurniawan, T.A. Various treatment technologies to remove arsenic and mercury from contaminated groundwater: An overview. In Proceedings of the Southeast Asian Water Environment 1: Selected Papers from the First International Symposium on Southeast Aian Water Environment (biodiversity and Water Environment), Bangkok, Thailand, 1 December 2005.

14. Coupal, B.; Lalancette, J.-M. The treatment of waste waters with peat moss. Water Res. 1976, 10, 1071-1076. [CrossRef]

15. McLellan, J.; Rock, C. Pretreating landfill leachate with peat to remove metals. Water Air Soil Pollut. 1988, 37, 203-215. [CrossRef]

16. Chaney, R.L.; Hundemann, P.T. Use of peat moss columns to remove cadmium from wastewater. J. Water Pollut. Control Fed. 1979, 51, 17-21.

17. Sharma, D.; Forster, C. Removal of hexavalent chromium using sphagnum moss peat. Water Res. 1993, 27, 1201-1208. [CrossRef]

18. Gardea-Torresdey, J.; Tang, L.; Salvador, J. Copper adsorption by esterified and unesterified fractions of Sphagnum peat moss and its different humic substances. J. Hazard. Mater. 1996, 48, 191-206. [CrossRef]

19. Zhipei, Z.; Junlu, Y.; Zenghui, W.; Piya, C. A preliminary study of the removal of $\mathrm{Pb}(2+), \mathrm{Cd}(2+), \mathrm{Zn}(2+)$, $\mathrm{Ni}(2+)$, and $\mathrm{Cr}(2+)$ from wastewater with several Chinese peats. In Proceedings of the Seventh International Peat Congress, Dublin, Ireland, 18-23 June 1984; pp. 147-152.

20. Dennehy, C.; Lawlor, P.G.; Jiang, Y.; Gardiner, G.E.; Xie, S.; Nghiem, L.D.; Zhan, X. Green-house gas emissions from different pig manure management techniques: A critical analysis. Front. Environ. Sci. Eng. 2017, 11, 11.

21. Feng, Z.; Zhu, L. Sorption of phenanthrene to biochar modified by base. Front. Environ. Sci. Eng. 2017, $12,1$. [CrossRef]

22. Li, Z.; Wang, F.; Bai, T.; Tao, J.; Guo, J.; Yang, M.; Wang, S.; Hu, S. Lead immobilization by geological fluorapatite and fungus Aspergillus niger. J. Hazard. Mater. 2016, 320, 386-392. [CrossRef]

23. Shen, Z.; Zhang, Y.; Jin, F.; McMillan, O.; Al-Tabbaa, A. Qualitative and quantitative characterisation of adsorption mechanisms of lead on four biochars. Sci. Total Environ. 2017, 609, 1401-1410. [CrossRef]

24. Lee, S.-J.; Park, J.H.; Ahn, Y.-T.; Chung, J.W. Comparison of Heavy Metal Adsorption by Peat Moss and Peat Moss-Derived Biochar Produced Under Different Carbonization Conditions. Water Air Soil Pollut. 2015, 226, 9. [CrossRef]

25. Teir, S.; Eloneva, S.; Fogelholm, C.-J.; Zevenhoven, R. Stability of calcium carbonate and magnesium carbonate in rainwater and nitric acid solutions. Energy Convers. Manag. 2006, 47, 3059-3068. [CrossRef]

26. Petrounias, P.; Rogkala, A.; Giannakopoulou, P.P.; Tsikouras, B.; Lampropoulou, P.; Kalaitzidis, S.; Hatzipanagiotou, K.; Lambrakis, N.; Christopoulou, M.A. An Experimental Study for the Remediation of Industrial Waste Water Using a Combination of Low Cost Mineral Raw Materials. Minerals 2019, 9, 207. [CrossRef]

27. Smith, M. Panasqueira the tungsten giant at 100+. Oper. Focus Int. Min. 2006, 33, 10-14. 
28. Brigatti, M.F.; Galán, E.; Theng, B. Chapter 2 Structures and Mineralogy of Clay Minerals. In Developments in Clay Science; Elsevier: Amsterdam, The Netherlands, 2006; Volume 1, pp. 19-86, ISBN 9780080441832.2006.

29. Sengupta, A.; Kadam, R.; Rajeswari, B.; Dhobale, A.; Babu, Y.; Godbole, S. Characterization of Indian serpentine by $\mathrm{X}$-ray diffraction, photoacoustic spectroscopy and electron paramagnetic resonance spectroscopy. Appl. Clay Sci. 2010, 50, 305-310. [CrossRef]

30. Auzende, A.-L.; Pellenq, R.J.-M.; Devouard, B.; Baronnet, A.; Grauby, O. Atomistic calculations of structural and elastic properties of serpentine minerals: The case of lizardite. Phys. Chem. Miner. 2006, 33, 266-275. [CrossRef]

31. Huang, P.; Li, Z.; Chen, M.; Hu, H.; Lei, Z.; Zhang, Q.; Yuan, W. Mechanochemical activation of serpentine for recovering CU (II) from waste water. Appl. Clay Sci. 2017, 149, 1-7. [CrossRef]

32. Rogkala, A.; Petrounias, P.; Tsikouras, B.; Hatzipanagiotou, K. New Occurrence of Pyroxenites in the Veria-Naousa Ophiolite (North Greece): Implications on Their Origin and Petrogenetic Evolution. Geoscience 2017, 7, 92. [CrossRef]

33. Brunn, J.H. Geological Map of Greece, Veroia Sheet, 1:50.000; IGME: Athens, Greece, 1982.

34. Decourt, J.; Aubouin, J.; Savoyat, E. Le sillon mesohellenique et la zone pelagonienne. Bull. Soc. Geoli. Fr. 1977, 1, 32-70.

35. Michailidis, K. Zoned chromites with high Mn-contents in the Fe-Ni-Cr-laterite ore deposits from the Edessa area in Northern Greece. Miner. Depos. 1990, 25, 190-197. [CrossRef]

36. Rogkala, A.; Petrounias, P.; Tsikouras, B.; Giannakopoulou, P.P.; Hatzipanagiotou, K. Mineralogical Evidence for Partial Melting and Melt-Rock Interaction Processes in the Mantle Peridotites of Edessa Ophiolite (North Greece). Minerals 2019, 9, 120. [CrossRef]

37. Tarney JPe-Piper, G.; Piper, D.J.W. The Igneous Rocks of Greece. The Anatomy of an Orogen. Beiträge zur Regionalen Geologie der Erde (Series). Geol. Mag. 2003, 140, 357. [CrossRef]

38. Saccani, E.; Photiades, A.; Santato, A.; Zeda, O. New evidence for supra-subduction zone ophiolites in the Vardar zone of northern Greece: Implications for the tectonomagmatic evolution of the Vardar oceanic basin. Ofioliti 2008, 33, 65-85.

39. Mercier, J.L.; Vergely, P. Geological Map of Greece, Edhessa Sheet, 1:50.000; IGME: Athens, Greece, 1984.

40. Bish, D.L.; Post, J.E. Quantitative mineralogical analysis using the Rietveld full pattern fitting method. Am. Mineral. 1993, 78, 932-940.

41. Singh, A.K.; Singh, R.B. Genetic implications of Zn- and Mn-rich Cr-spinels in serpentinites of the Tidding Suture Zone, eastern Himalaya, NE India. Geol. J. 2012, 48, 22-38. [CrossRef]

42. Chen, M.; Li, Z.; Li, X.; Qu, J.; Zhang, Q. Mechanochemically extracting tungsten through caustic processing of scheelite by controlling calcium dissolution. Int. J. Refract. Met. Hard Mater. 2016, 58, 211-215. [CrossRef]

43. James, S.L.; Adams, C.J.; Bolm, C.; Braga, D.; Collier, P.; Friščić, T.; Grepioni, F.; Harris, K.D.M.; Hyett, G.; Jones, W.; et al. Mechanochemistry: Opportunities for new and cleaner synthesis. Chem. Soc. Rev. 2012, 41, 413-447. [CrossRef]

44. Vdović, N.; Jurina, I.; Škapin, S.D.; Sondi, I. The surface properties of clay minerals modified by intensive dry milling-Revisited. Appl. Clay Sci. 2010, 48, 575-580. [CrossRef]

45. Li, J.; Hitch, M. Mechanical activation of ultramafic mine waste rock in dry condition for enhanced mineral carbonation. Miner. Eng. 2016, 95, 1-4. [CrossRef]

46. Vijayaraghavan, K.; Yun, Y.-S. Bacterial biosorbents and biosorption. Biotechnol. Adv. 2008, 26, $266-291$. [CrossRef]

47. Dutta, D.; Kumari, A.; Panda, R.; Jha, S.; Gupta, D.; Goel, S.; Jha, M.K. Close loop separation process for the recovery of Co, Cu, Mn, Fe and Li from spent lithium-ion batteries. Sep. Purif. Technol. 2018, 200, 327-334. [CrossRef]

48. Petrounias, P.; Giannakopoulou, P.P.; Rogkala, A.; Stamatis, P.M.; Tsikouras, B.; Papoulis, D.; Lampropoulou, P.; Hatzipanagiotou, K. The Influence of Alteration of Aggregates on the Quality of the Concrete: A Case Study from Serpentinites and Andesites from Central Macedonia (North Greece). Geosciences 2018, 8, 115. [CrossRef]

49. Petrounias, P.; Giannakopoulou, P.P.; Rogkala, A.; Stamatis, P.M.; Lampropoulou, P.; Tsikouras, B.; Hatzipanagiotou, K. The Effect of Petrographic Characteristics and Physico-Mechanical Properties of Aggregates on the Quality of Concrete. Minerals 2018, 8, 577. [CrossRef]

(C) 2020 by the authors. Licensee MDPI, Basel, Switzerland. This article is an open access article distributed under the terms and conditions of the Creative Commons Attribution (CC BY) license (http://creativecommons.org/licenses/by/4.0/). 